\title{
PERKAWINAN DALAM PERSPEKTIF ISLAM; SEBUAH TINJAUAN FILOSOFIS
}

\author{
Muhamad Zainal Mawahib \\ Fakultas Syariah dan Hukum UIN Walisongo Semarang \\ mawahib.zainal@gmail.com
}

\begin{abstract}
This paper examines the philosophical review of marriage in an Islamic perspective. Issues that are always actual and always interesting are explored, considering that this problem is not only about the nature and purpose of human life that is merely human. But it also touches on a noble and central institution, namely a community institution called household or family. This institution is a stronghold for the defense of human dignity and noble and most central moral values. With a philosophical approach, this paper finds that Islamic law is present not only to allow husband and wife relations, but to have a broader philosophical meaning, namely for the welfare of the people, both individually and in society, both for life in the world and in the hereafter. Community welfare will be achieved by creating prosperous family welfare. Because family is the smallest institution in society in a country. This means that people's welfare is very dependent on family welfare.
\end{abstract}

Keyword: Marriage, Islamic Perspective, Philosophical, Family

\begin{abstract}
Abstrak
Tulisan ini mengkaji tentang tinjauan filosofis perkawinan dalam perspektif Islam. Persoalan yang selalu aktual dan selalu menarik ditelurusi, mengingat permasalahn ini bukan hanya menyangkut tabiat dan hajat hidup manusia yang asasi semata. Tetapi juga menyentuh suatu lembaga yang luhur dan sentral yaitu sebuah lembaga masyarakat yang disebut dengan rumah tangga atau keluarga. Lembaga ini merupakan benteng bagi pertahanan martabat manusia dan nilai-nilai akhlak yan gluhur dan paling sentral. Dengan pendekatan filosofis, tulisan ini menemukan bahwa hukum Islam hadir bukan semata untuk membolehkan hubungan suami istri, namun memiliki makna filosofis yang lebih luas, yakni untuk kesejahteraan umat, baik secara perorangan maupun secara bermasyarakat, baik untuk hidup di dunia maupun di akhirat. Kesejahteraan masyarakat akan tercapai dengan terciptanya kesejahteraan keluarga yang sejahtera. Karena keluarga merupakan lembaga terkecil dalam masyarakat dalam sebuah Negara. Ini artinya kesejahteraan masyarakat sangat tergantung kepada kesejahteraan keluarga.
\end{abstract}

Kata Kunci: Perkawinan, Perpsektif Islam, Filofosif, Keluarga 


\section{A. Pendahuluan}

Al-Qur'an yang diturunkan oleh Allah Swt. kepada Nabi Muhammad Saw. yang diperuntukkan kepada semua umat Islam, tujuannya tidak lain sebagai sumber hukum dan pedoman manusia dalam berkehidupan di dunia. Tentunya pedoman yang berupa peraturan-peraturan yang terkandung di dalamnya memiliki tujuan yang positif bagi seluruh umat manusia.

Memahami peraturan yang terkadung di dalam teks suci alQur'an perlu menggalinya secara mendalam terhadap keberadaan pedoman tersebut. Sehingga dapat ditemukan hakikat sebenarnya dari pedoman atau hukum itu sendiri. Dengan pengertian yang tepat dalam memaknai hukum tersebut, diharapkan akan menjadi penghormatan terhadap hukum yang ada dan juga menimbulkan semangat untuk selalu menjunjung tinggi hukum tersebut. Menurut Theo Huijbers pemahaman yang mendekati sempurna terhadap suatu hukum itu sendiri dipercaya sebagai hal yang dapat memperpendek jarak antara hukum dan keadilan sehingga dipasang sebagai cita-cita yang harus dilaksanakan. ${ }^{1}$

Salah satu yang diatur dalam agama Islam adalah persoalan pernikahan atau perkawinan. ${ }^{2}$ Persoalan yang selalu aktual dan selalu menarik untuk diperdalami ini menjadi penting sekali karena

\footnotetext{
${ }^{1}$ Theo Huijbers, Filsafat Hukum, Yogyakarta: Kanusius, 1995, hlm. 11.

${ }^{2}$ Istilah pernikahan dan perkawinan dalam tulisan ini adalah suatu istilah yang sama, sebagaimana tercantum dalam Undang-undang Perkawinan Nomor 1 Tahun 2974 pada pasal 1, Perkawinan diartikan sebagai ikatan lahir batin antara seorang pria dan seorang wanita sebagai suami istri dengan tujuan membentuk keluarga atau rumah tangga yang bahagia dan kekal berdasarkan Ketuhanan Yang Maha Esa. Diperjelas dengan Pasal 2 Ayat 1, yang berbunyi perkawinan adalah sah apabila dilakukan menurut hukum masing-masing agama dan kepercayaannya itu.
} 
persoalan ini bukan hanya menyangkut tabiat dan hajat hidup manusia yang asasi semata. Tetapi juga menyentuh suatu lembaga yang luhur dan sentral yaitu sebuah lembaga yang disebut dengan rumah tangga. Lembaga ini merupakan benteng bagi pertahanan martabat manusia dan nilai-nilak akhlak yan luhur dan paling sentral.

Tujuan yang luhur ini sering kali dilupakan oleh umat Islam. Fenomena perceraian seperti sudah menjadi hal yang biasa. Hal ini tidak lain karena umat Islam hanya melihat satu sisi dari perkawinan tersebut. Namun sejatinya di dalam tujuan yang luhur perkawinan memiliki filosofis yang harus diketahui oleh umat Islam sebagai bekal untuk mencapai cita-cita tersebut.

Agama Islam yang dikenal dan diyakini selama ini sebagai agama yang akan membawa manusia kepada kebahagiaan dunia dan akhirat. Namun apakah Islam yang dikenal dan diyakini itu memang begitu adanya atau banyak hal yang pada hakikatnya tidak sesuai dengan apa yang sebenarnya diajarkan Nabi Muhammad Saw, sebagai penyampai wahyu dari Allah Swt. Berbagai pertanyaan menelisik tentang perkawinan sebagai salah satu pedoman dalam Islam masih sering muncul di benak umat manusia. Hal ini karena agama Islam bagaikan sebuah bola yang mengapung di atas air, sehingga tidak bisa mengetahui bola itu secara utuh. Begitu pula dengan Islam, Islam bukan monodimensi tapi multidimensi, jika ingin memahaminya secara menyeluruh dan mendalam, maka diperlukan sebuah pendekatan untuk memahaminya.

Melalui pendekatan filosofi diharapkan dapat mengupas sedalam-dalamnya peraturan tentang perkawinan dalam Islam. Di mana pendekatan filosofis merupakan kegiatan berpikir secara 
mendalam yang sistematik, radikal dan universal dalam rangka mencari kebenaran, inti hikmah atau hakikat mengenai segala sesuatu yang ada. ${ }^{3}$

Berpikir secara filosofis tersebut selanjutnya dapat digunakan dalam memahami ajaran agama, dengan maksud agar hikmah, hakikat atau inti dari ajaran agama dapat dimengerti dan dipahami secara seksama. Dengan tinjauan filosofis ini diharapkan akan diperoleh sebuah pemahaman yang lebih baik dan komprehensif mengenai makna filosofi perkawinan dalam kehidupan manusia.

\section{A. Definisi dan Fiqih Perkawinan}

1. Definisi Perkawinan

Dalam Kamus Besar Basaha Indonesia, perkawinan berasal dari kata "kawin" yang menurut bahasa artinya membentuk keluarga dengan lawan jenis, melakukan hubungan kelamin atau bersetubuh. ${ }^{4}$ Perkawinan juga disebut dengan "pernikahan", berasal dari kata nikah yang menurut bahasa artinya mengumpulkan, saling memasukkan dan digunakan untuk arti bersetubuh. ${ }^{5}$

Dalam terminologi hukum Islam, terdapat banyak definisi, di antaranya pandangan Wahbah al-Zuhaili, menurutnya perkawinan adalah sebuah akad yang ditetapkan oleh syara' untuk membolehkan bersenang-senang antara laki-laki dengan perempuan dan

${ }^{3}$ Sidi Gazalba, Sistematika Filsafat, jilid I, Jakarta: Bulan Bintang, 1967, hlm. 15.

${ }^{4}$ Dep Dikbud, Kamus Besar Bahasa Indonesia, Jakarta: Balai Pustaka, 1994, hlm. 456.

${ }^{5}$ Lihat Ahmad Warson Munawwir, Al-Munawwir Kamus Arab - Indonesia, Cet. XXV, Surabaya: Pustaka Progessif, 2002, hlm. 1461, lihat juga Muhammad Ismail bin Ismail al-Kahlaniy, Subul al-Salam, bandung: Dahlan, t.t., hlm. 109, lihat juga Wahbah al-Zuhaili, al-Fiqh al-Islami wa Adillatuh, Beirut: Dar al-Fikr, 1989, hlm. 29. 
menghalalkan bersenang-senangnya perempuan dengan laki-laki. ${ }^{6}$ Sedangkan menurut Abu Yahya Zakariya al-Anshary menikah adalah akad yang mengandung ketentuan hukum kebolehan hubungan seksual dengan lafadz nikah atau dengan kata-kata yang semakna dengannya. ${ }^{7}$ Pandangan ini semakna yang diberikan oleh Zakiah Daradjat yang mendefinisikan menikah sebagai sebuah akad yang mengandung ketentuan hukum kebolehan hubungan seksual dengan lafadz nikah atau tazwij atau semakna dengan keduanya. ${ }^{8}$

Pengertian di atas memberi pemahaman bahwa seakan perkawinan hanya sebagai ritual untuk dibolehkannya hubungan antara laki-laki dengan perempuan yang semula dilarang menjadi dibolehkan. Padahal setiap perbuatan hukum itu mempuyai tujuan dan akibat hukum ataupun pengaruhnya. ${ }^{9}$ Hal inilah yang menjadi perhatian manusia pada umumnya dalam kehidupan sehari-hari seperti terjadi perceraian, kurang keseimbangan antara suami istri. sehingga memerlukan sebuah ketegasan tentang arti perkawinan. Ketegasan tersebut tidak hanya berupa kebolehan bersetubuh semata tetapi ada sebuah tujuan dan akibat hukum dari prosesi akad nikah tersebut.

Dalam kaitan ini, Muhammad Abu Ishrah memberikan pengertian perkawinan yang lebih luas. menurutnya perkawinan adalah akad yang memberikan faidah hukum kebolehan mengadakan hubungan keluarga antara laki-laki dan perempuan dan mengadakan

${ }^{6}$ Ibid.

${ }^{7}$ Abu Yahya Zakariya al-Anshary, Fath al-Wahhab, Singapura: Sulaiman Mar'iy, t.t., hlm. 30.

${ }^{8}$ Zakiah Daradjat, Ilmu Fiqh, Yogyakarta: Dana Bhakti Wakaf, 1995, hlm. 37.

${ }^{9}$ Abd Rahman al-Ghazaly, Fiqh Munakahat, Jakarta: Kencana, 1996, hlm. 9. 
tolong-menolong dan memberi batas hak bagi pemiliknya serta pemenuhan kewajiban bagi masing-masing. ${ }^{10}$

Berkaitan dengan perkawinan ini Sayyid Sabiq memberikan sebuah komentar yang filosofis mengenai perkawinan itu sendiri. Menurut Sayyid Sabiq, perkawinan merupakan salah satu sunnatullah yang berlaku pada semua makhluk Tuhan, baik manusia, hewan maupun tumbuh-tumbuhan. Perkawinan merupakan cara yang dipilih oleh Allah sebagai jalan bagi manusia untuk beranak-pinak dan melestarikan hidupnya setelah masing-masing pasangan siap melakukan perannya yang prositif dalam mewujudkan tujuan perkawinan. Allah tidak menjadikan manusia seperti makhluk lainnya yang hidup bebas mengikuti nalurinya dan berhubungan secara anarki tanpa aturan. ${ }^{11}$

Demi menjaga kehormatan dan martabat kemuliaan manusia, sehingga hubungan laki-laki dan perempuan diatur secara terhormat dan berdasarkan rasa saling meridhai, dengan ijab qabul sebagai lambang adanya rasa ridha-meridhai dan dengan dihindari dengan para saksi yang menyaksikan bahwa pasangan laki-laki dan perempuan itu telah saling terikat. ${ }^{12}$

Bentuk perkawinan ini telah memberikan jalan yang aman pada naluri seks, memelihara keturanan dengan baik dan menjaga kaum perempuan agar tidak laksana rumput yang bisa dimakan oleh binatang ternak dengan seenaknya. Pergaulan saumi istri menurut ajaran Islam diletakkan di bawah naluri keibuaan dan kebapakan

\begin{tabular}{|c|c|}
\hline & $\begin{array}{l}{ }^{10} \text { Zakiah Daradjat, loc.cit. } \\
{ }^{11} \text { Sayyid Sabiq, Fiqh al-Sunnah, jilid. 3, Beirut: Dar al-Fikr, 1983, hlm. } 5 . \\
{ }^{12} \text { Ibid. }\end{array}$ \\
\hline 55 & Muhamad Zainal Mawahib \\
\hline
\end{tabular}


sebagaimana ladang yang baik yang nantinya menumbuhkan tumbuhtumbuhan yang baik dan menghasilkan buah yang baik pula. ${ }^{13} \mathrm{Hal}$ demikian lah yang diharapkan dari adanya perkawinan. Untuk menciptakan hal tersebut agama Islam datang untuk memberikan pedoman dan peraturan yang berkaitan dengan perkawinan.

2. Hukum Melakukan Perkawinan dalam Islam

Para ulama berbeda pendapat tentang persoalan hukum asal melakukan pernikahan. Menurut jumhur ulama (mayoritas ulama) hukum nikah wajib. Sedangkan sebagian ulama yang lain seperti, golongan Zhahiriyah mengatakan bahwa hukum asal nikah sunnah. Menurut Ibnu Rusyd perbedaan pendapat ini karena perbedaan penafsiran apakah bentuk perintah dalam ayat dan hadist yang kenaan dengan dalil perkawinan. ${ }^{14}$ Bahkan ada yang menyatakan mubah, seperti ulama syafi'iyyah. ${ }^{15}$

Sedangkan apabila perkawinan tersebut dilihat dari keadaan orang yang melakukan perkawinan, maka Abdurrahman al-Jaziry menyimpulkan bahwa hukum nikah berlaku untuk hukum-hukum syara' yang lima, adakalnya wajib, haram, makruh, sunnah dan mubah. $^{16}$

Terlepas dari perbedaan pandangan ulama tentang hukum perkawinan yang mereka juga merujuk berdasarkan nash-nash, baik

${ }^{13}$ Selengkapnya lihat Ibid.

${ }^{14}$ Ibnu Rusyd, Bidayah al-Mujtahid wa Nihayah al-Muqtashid, jilid. 2, Beirut: Dar al-Fikr, t.t., hlm. 2.

${ }^{15}$ Selengkapnya lihat Depag RI, Ilmu Fiqh II, Jakarta: Dirjen Bimbingan Islam, 1985, hlm. 55-58.

${ }^{16}$ Abdurrahaman al-Jaziry, Kitab al-Fiqh 'ala al-Mazahib al-Arba'ah, jilid. 7, Mesir: Dar al-Irsyad, t.t., hlm. 4. 
al-Qur'an maupun hadits, di mana Islam sangat menganjurkan umat

Islam yang sudah mampu menikah untuk melakukan pernikahan.

3. Syarat dan Rukun Perkawinan dalam Islam

Jumhur ulama sepakat bahwa rukun perkawinan terdiri atas: ${ }^{17}$

a. Adanya calon suami dan calon istri yang akan melakukan perkawinan

b. Adanya wali dari pihak calon pengantin perempuan

c. Adanya dua orang saksi

d. Sighat akad nikah, yaitu ijab qabul yang diucapkan oleh wali atau wakilnya dari pihak wanita dan dijawab oleh calon suami.

Sedangkan untuk syarat sahnya perkawinan secara garis besar ada dua, yaitu:

a. Calon mempelai perempuannya halal dikawin oleh laki-laki yang ingin menjadikannya istri. ${ }^{18}$

b. Akad nikahnya dihadiri para saksi.

\section{B. Pandangan Islam tentang Perkawinan dalam al-Qur'an dan Hadits}

Dalam al-Qur'an dinyatakan bahwa hidup berpasangpasangan, berjodoh-jodoh adalah naluri segala makhluk Allah, termasuk manusia. Sebagaimana dalam surat Az-Zariyat: 49.

"Dan segala sesuatu Kami ciptakan berpasang-pasangan supaya kamu mengingat kebesaran Allah" (QS. Adz-Dzariyat: 49) $)^{19}$

${ }^{17}$ Selengkapnya lihat Slamet Abidin dan H. Aminuddin, Fiqih Munakahat II, Bandung: Pustaka Setia, 1999, hlm. 64-68.

18 Selengkapnya untuk syarat-syarat calon suami dan calon istri lihar, ZakiahDaradjat, op.cit., hlm. 38-41. 
Dalam surat Yasin: 36.

"Maha Suci Allah yang telah menciptakan pasangan-pasangan semuanya, baik dari apa yang ditumbuhkan oleh bumi dan dari diri mereka maupun dari apa yang tidak mereka ketahui”, (QS. Yasin: 36$)^{20}$

Dari makhluk yang diciptakan oleh Allah Swt. berpasangpasanga inilah Allah Swt. menciptakan manusia menjadi berkembang biak dan berlangsung dari generasi ke generasi berikutnya. Sebagaimana termaktub dalam surat an-Nisa': 1:

"Hai sekalian manusia, bertakwalah kepada Tuhan-mu yang telah menciptakan kamu dari seorang diri, dan dari padanya Allah menciptakan isterinya; dan dari pada keduanya Allah memperkembang biakkan laki-laki dan perempuan yang banyak. Dan bertakwalah kepada Allah yang dengan (mempergunakan) nama-Nya kamu saling meminta satu sama lain, dan (peliharalah) hubungan silaturrahim. Sesungguhnya Allah selalu menjaga dan mengawasi kamu”, (QS. an-Nisa: $1)^{21}$

Hal ini juga termaktub dalam surat an-Nahl: 72:

"Allah menjadikan bagi kamu isteri-isteri dari jenis kamu sendiri dan menjadikan bagimu dari isteri-isteri kamu itu, anak-anak dan cucu-cucu, dan memberimu rezki dari yang baik-baik. Maka mengapakah mereka beriman kepada yang bathil dan mengingkari nikmat Allah ?'”, (QS. an-Nahl: 72) $)^{22}$

Agama Islam mengatur manusia dalam hidup berjodoh-jodoh itu melalui jenjang perkawinan yang ketentuannya dirumuskan dalam wujud aturan-aturan yang disebut dengan hukum perkawinan. Hukum ini ada bukan tanpa adanya sebuah tujuan, namun hukum Islam juga

${ }^{19}$ Departemen Agama RI, al-Qur'an dan Terjemahannya, Bandung: Syaamil Cipta Media, 2005, hlm. 522.

${ }^{20}$ Ibid., hlm. 442.

${ }^{21}$ Ibid., hlm. 77.

${ }^{22}$ Ibid., hlm. 274. 
ditetapkan ini untuk kesejahteraan umat, baik secara perorangan maupun secara bermasyarakat, baik untuk hidup di dunia maupun di akhirat. Kesejahteraan masyarakat akan tercapai dengan terciptanya kesejahteraan keluarga yang sejahtera. Karena keluarga merupakan lembaga terkecil dalam masyarakat, sehingga kesejahteraan masyarakat sangat tergantung kepada kesejahteraan keluarga.

Demikian pula kesejahteraan perorangan sangat dipengaruhi oleh kesejahteraan keluarga. Islam mengatur keluarga bukan secara garis besar, tetapi sampai terperinci. Hal demikian menunjukkan perhatian yang sangat besar terhadap kesejahteraan keluarga. keluarga terbentuk melalui perkawinan, karena itu perkawinan sangat dianjurkan oleh islam bagi yang telah memiliki kemampuan. Tujuan itu dinyatakan dalam al-Qur'an dan hadits. Dalam al-Qur'an dinyatakan bahwa berkeluarga itu termasuk sunnah rasul-rasul sejak dahulu sampai rasul terakhir Nabi Muhammad Saw, sebagaiman termaktub dalam surat ar-Ra'd: 38 :

"Dan sesungguhnya Kami telah mengutus beberapa Rasul sebelum kamu dan Kami memberikan kepada mereka isteriisteri dan keturunan. Dan tidak ada hak bagi seorang Rasul mendatangkan sesuatu ayat (mukjizat) melainkan dengan izin Allah. Bagi tiap-tiap masa ada Kitab (yang tertentu)", (QS. arRa'd: 38$)^{23}$

Sabda Nabi Muhammad Saw. yang diriwayatkan oleh Imam Bukhori dan Imam Muslim:

"Dari Anas Ra. Bahwasanya Nabi Saw. berkata: ...tetapi aku, sesungguhnya aku salat, tidur, berbuka dan mengawini

${ }^{23}$ Ibid., hlm. 254. 
perempuan, maka barang siapa yang benci sunnahku maka ia bukanlah dari golonganku", (HR. Bukhari dan Muslim) ${ }^{24}$

Menikah dalam Islam menganjurkan terlebih bagi mereka yang membujang. Mereka dianjurkan untuk menciptakan sebuah keluarga. Islam juga menganjurkan orang yang berkeluarga karena dari segi batin orang dapat dicapainya melalui keluarga yang baik, sebagaimana hadits yang diriwayatkan oleh Bukhari dan Muslim.

"Dari Ibnu Mas'ud Ra. berkata, Rasulullah Saw. mengatakan kepada kami: Hai sekalian pemuda, barang siapa di antara kamu yang telah sanggup melaksanakan akad nikah, hendaklah melaksanakannya. Maka sesungguhnya melakukan akad nikah itu (dapat) menjaga pandangan dan memelihara farji (kemaluan), dan barang siapa yang belum sanggup hendaklah ia berpuasa (sunat), maka sesunguhnya puasa itu perisai baginya", (HR. Bukhari dan Muslim) ${ }^{25}$

Begitu istimewanya sebuah akibat dari perkawinan, hal ini terlihat dari segi ketentuan bertambah dan berkesinambungannya amal kebaikan sekarang dengan berkeluarga akan dapat dipenuhi. Dengan berkeluarga orang dapat mempunyai anak dari anak yang shaleh diharapkan mendapatkan amal tambahan di samping amalamal jariyah yang lain. Sebagaimana sabda Nabi Muhammad Saw yang diriwayatkan oleh Imam Muslim.

"Jika seseorang meninggal dunia, maka terputuslah amalannya kecuali tiga perkara yaitu: sedekah jariyah, ilmu yang dimanfaatkan, atau do'a anak yang sholeh" (HR. Imam Muslim) $)^{26}$

${ }^{24}$ Ibnu Hajar al-Asqalani, Bulugh al-Maram, Beirut: Dar al-Ihya' al-Ulum, 1991, hlm. 401

${ }^{25}$ Ibid.

${ }^{26}$ Muslim ibn al-Hajjaj al-Qushayri al-Naysaburi, Shahih Muslim, Riyadh: Dar al-Mughni, 1998, hlm. 886. 
Uraian tersebut menunjukkan bahwa agama Islam menginginkan sebuah rumah tangga yang kemudian juga dikenal dengan keluarga dalam rangka mendirikan keluarga yang harmonis, sejahtera dan bahagia. Harmonis dalam menggunakan hak dan kewajiban anggota keluarga. Sejahtera artinya terciptanya ketenangan lahir dan batin disebabkan dan terpenuhinya keperluan hidup lahir dan batinnya, sehingga timbullah kebahagiaan, yakni kasih sayang antar anggota keluarga dan lebih umumnya untuk seluruh masyarakat.

\section{Tinjauan Filosofis Perkawinan dalam Perspektif Islam}

\section{Perkawinan dan Kesejahteraan Manusia}

Al-Jurjawi memahami bahwa pada dasarnya, Allah Swt. menciptakan manusia untuk meramaikan dan memasyarakatkan dunia ini yang di dalamnya telah diisi dengan berbagai ciptaan Allah Swt. Kelangsungan kehidupan di dunia ini mensyarakatnya adanya manusia hingga dunia ini berakhir. Kelansungan hidup ini memerlukan perkembangbiakan bangsa manusia dan menjaganya, sehingga tidak ada sesuatu yang sia-sia dalam penciptakan bumi dan seisinya. ${ }^{27}$ Hal ini karena segala ciptaan Allah Swt. mengandung maksud dan manfaat. Oleh karena itu, sebagai makhluk yang paling mulia, sekaligus sebagai khalifah di muka bumi, manusia harus menyadari terhadap tujuan hidupnya.

Keberadaan manusia di muka bumi ini bukanlah ada dengan sendirinya. Manusia diciptakan oleh Allah, dengan dibekali potensi

${ }^{27}$ Ali Ahmad al-Jurjawi, Hikmah al-Tasyri' wa Falsafatuhu, Juz. II, Beirut: Dar al-Fikr, 1994, hlm. 4. Hal ini sebagaimana yang dijelaskan dalam Qs. as-Shod: 27, lihat Departemen Agama RI, op.cit., hlm. 453. 
dan infrastruktur yang sangat unik. Keunikan dan kesempurnaan bentuk manusia ini bukan saja dilihat dari bentuknya, akan tetapi juga dari karakter dan sifat yang dimiliki oleh manusia. Sebagai ciptaan, manusia dituntut memiliki kesadaran terhadap posisi dan kedudukan dirinya di hadapan Tuhan. Dalam konteks ini manusia di hadapan Tuhannya sebagai hamba yang harus menunjukkan sifat pengabdian dan kepatuhannya sebagai wujud beribadah kepada-Nya. ${ }^{28}$

Manusia juga dijadikan sebagai khalifah di muka bumi, ${ }^{29}$ bahkan secara tegas Allah menyatakan bahwa manusia ditumbuhkan dari bumi dan selanjutnya diserahi untuk memakmurkannya. Dengan demikian seluruh urusan kehidupan manusia dan eksistensi alam semesta di dunia ini telah diserahkan Allah kepada manusia. Perintah memakmurkan alam, ini berarti perintah untuk menjadikan alam semesta ini sebagai media untuk mewujudkan kemaslahatan hidup manusia di dunia.

Dalam rangka merealisasikan hal itu manusia harus bekerjasama dengan manusia yang lain. Gotong royong antar manusia menjadikan mereka semakin kompak untuk menjalannya. Karena manusia tidak akan mampu mengandalkan kemampuan atau kekuatannya sendiri. Manusia membutuhkan manusia yang lain dalam beberapa hal dalam mewujudkan eksistensinya. Salah satunya untuk

${ }^{28}$ Hal ini tercermin dalam QS. adz-Dzariyat: 56: "Dan aku tidak menciptakan jin dan manusia melainkan supaya mereka mengabdi kepada-Ku." (QS. adz-Dzariyat: 56), lihat Departemen Agama RI, op.cit., hlm. hlm. 523.

29 QS. al-Baqarah: 30: "Ingatlah ketika Tuhanmu berfirman kepada para Malaikat: "Sesungguhnya Aku hendak menjadikan seorang khalifah di muka bumi." Mereka berkata: "Mengapa Engkau hendak menjadikan (khalifah) di bumi itu orang yang akan membuat kerusakan padanya dan menumpahkan darah, padahal kami senantiasa bertasbih dengan memuji Engkau dan mensucikan Engkau?" Tuhan berfirman: "Sesungguhnya Aku mengetahui apa yang tidak kamu ketahui"” (QS. alBaqarah: 30), lihat Departemen Agama RI, op.cit., hlm. hlm. 6. 
mengembangbiakan keturunan mereka dengan melalui sebuah perkawinan.

Dalam rangka melangsungkan keturunan dan tentunya keturunan tersebut dalam melanjutkan untuk merawat dunia ini dibutuhkan sebuah institusi yang mengaturnya. Melalui sebuah lembaga yang disebut dengan keluarga ini nanti, diharapkan manusia dapat mencetak generasi yang baik dan bisa menjadi hamba yang baik pula. Dalam proses untuk mencapai tujuan tersebut, Allah Swt. Melalui kitab suci al-Qur'an dan hadits dari Nabi Muhammad Saw. Memberikan pedoman dan peraturan sedemikian rupa, yaitu adanya sistem perkawinan dengan berbagai rukun dan syaratnya.

Andai sistem pedoman yang disebut dengan perkawinan ini tidak ada, maka manusia akan saling bermusuhan antara satu dengan yang lain. Akibatnya status anak pun menjadi tidak jelas karena mereka bisa berhubungan badan dengan siapa saja. Penyakit menular akan menyebar ke mana-mana. Kepedulian untuk merawat bumi ini semakin hilang, karena mereka hanya mementingkan diri sendiri. Kebebasan mereka pun dijalani tanpa sebuah batasan.

Hadirnya sistem perkawinan dengan seperangkat peraturan dan pedoman bermaksud untuk mengatasi problem yang dikhawatirkan tersebut. Melalui lembaga yang paling kecil dalam sebuah negara ini akan berperan penting dalam membentuk generasi yang baik. mereka dapat memberikan pendidikan mulai di dalam kandungan hingga generasi tersebut tumbuh kembang menuju kedewasaan. Berbagai pelajaran tentang dunia mereka dapatkan yang tidak luput dari peran adanya keluarga tersebut. Dengan demikian 
adanya sistem perkawinan ini tidak lain untuk membentuk manusia yang berakhlak mulia lelaui lembaga yang disebut dengan keluarga.

\section{Keluarga sebagai Tiang Negara}

Menurut penelusuran Quraish Shihab bahwa seluruh pakar dari berbagai disiplin ilmu, termasuk pakar agama Islam menyimpulkan bahwa keluarg adalah jiwa masyarakat dan tulang punggungnya. Kesejahteraan lahir dan batin yang dinikmati oleh suara bangsa atau sebaliknya, kebodohan dan keterbelakangannya, adalah cerminan dari keadaan keluarga-keluarga yang hidup pada masyarakat bangsa tersebut. ${ }^{30}$ Itulah antara lain yang menjadi alasan sehingga agama Islam memberikan perhatian yang sangat besar terhadap pembinaan keluarga, perhatian yang sepadan dengan perhatiannya terhadap individu serta kehidupan umat manusia secara keseluruhan.

Dalam al-Qur'an menganjurkan agar kehidupan keluarga menjadi bahan pemikiran setiap insan dan hendaknya darinya dapat ditarik pelajaran berharga. Karena al-Qur'an berpandangan bahwa kehidupan kekeluargaan, di samping menjadi salah stu tanda dari sekian banyak tanda-tanda kebesaran Ilahi, juga merupakan nikmat yang harus dapat dimanfaatkan sekaligus disyukuri. ${ }^{31}$

Demi terpeliharanya kehidupan keluarga yang harmonis dan unit kecil dari suatu negara ini menjalankan fungsinya dengan baik, hlm. 253.

${ }^{30}$ Quraish Shihab, Membumikan al-Qur'an, Cet. VII, Bandung: Mizan, 1994,

${ }^{31}$ Hal inilah yang tercermin dalam QS. ar-Rum: 21: "Dan di antara tanda-tanda kekuasaan-Nya ialah Dia menciptakan untukmu isteri-isteri dari jenismu sendiri, supaya kamu cenderung dan merasa tenteram kepadanya, dan dijadikan-Nya diantaramu rasa kasih dan sayang. Sesungguhnya pada yang demikian itu benar-benar terdapat tandatanda bagi kaum yang berpikir.”, (QS. ar-Rum: 21) dan juga dalam QS. ar-Rum: 72, lihat Departemen Agama RI, op.cit., hlm. 406 dan 274. 
maka Islam melalui syari'atnya menetapkan sekian banyak petunjuk dan peraturan. Hal ini penting sekali mengingat kehidupan dalam keluarga, Quraish Shihab mengibaratkan sebagai satu bangunan, demi terpeliharanya bangunan itu dari hantaman badai dan goncangan gempa, maka ia harus didirkan di atas satu fondasi yang kuat dengan bahan bangunan yang kokoh serta jalinan perekat yang lengket. Fondasi kehidupan kekeluargaan adalah ajaran agama, disertai dengan kesiapan fisik dan mental calon-calon bapak dan ibu. ${ }^{32}$

Bagi yang belum siap fisik, mental dan keuangannya, dianjurkan untuk bersabar dan tetap memelihara kesucian diri agar tidak terjerumus kelembah kehinaan. ${ }^{33}$ Sedangkan bagi yang sudah mampu fisik dan mental serta keuangannya dianjurkan untuk menikah. Tetapi demi kokohnya fondasi kehidupan keluarga maka dianjurkan agar menjadikan faktor keberagamaan calon pasangannya sebagai faktor yang amat menentukan pilihan. Sebagai hadits Nabi Muhammad Saw.: "Wanita dinikahi karena empat perkara, yaitu karena harta bendanya, karena kedudukannya, karena kecantikannya, dan karena agamanya. Maka pilihlah wanita yang memiliki agama ( kuat agamanya), niscaya kamu beruntung." (HR. Bukhari dan Muslim). ${ }^{34}$

Itulah gambaran dari kekuatan fondasi keluarga, sedangkan kekokohan bahan-bahan bangunannya tercermin antara lain dalam kewajiban memperhatikan buah perkawinan itu. Yakni

${ }^{32}$ Quraish Shihab, op.cit., hlm. 254,

${ }^{33}$ Sebagaimana dalam QS. an-Nur: 33; “Dan orang-orang yang tidak mampu kawin hendaklah menjaga kesucian (diri)nya, sehingga Allah memampukan mereka dengan karunia-Nya...”, (QS. an-Nur: 33), lihat Departemen Agama RI, op.cit., hlm. 354.

${ }^{34}$ Ibnu Hajar al-'Asqalany, Bulugh al-Marom, Beirut: Dar Ihya' al-Ulum, 1991, hlm. 403, lihat juga Muslim ibn al-Hajjaj al-Qushayri al-Naysaburi, op.cit., hlm. 772. 
memperhatikan terhadap anak-anak sejak masih dalam kandungan sampai dewasa. Tujuannya tidak lain untuk menciptakan generasi yang berakhlak mulia.

Adapun jalinan perekat bagi bangunan keluarga menurut Quraish Shihab adalah hak dan kewajiban yang disyariatkan Allah terhadap suami dan isteri serta anak-anaknya. Hak dan kewajiban serta peraturan yang ditetapkan tidak lain memiliki tujuan untuk menciptakan keharmonisan dalam hidup berumah tangga yang pada akhirnya menciptakan suasana aman, bahagia dan sejahtera bagi seluruh masyarakat bangsa. ${ }^{35}$ Lebih dari itu, Quraish Shihab memahami bahwa dalam al-Qur'an menamakan satu komunitas sebagai umat dan menamakan ibu yang melahirkan anak keturunan sebagai umm. Kedua kata tersebut memiliki akar kata yang sama. Ibu yang melahirkan dan pembinaan anak dan kehidupan rumah tangga merupakan tiang umat, tiang negara dan bangsa. Sehingga dalam literatur keagamaan dikenal ungkapan al-mar'ah 'imad al-bilad. Maka tidaklah meleset apabila dikatakan al-usrah 'imad al-bilad biha tahya wa biha tamut. ${ }^{36}$

Dalam keluarga seperti tempat putra-putri bangsa belajar. Dari sinilah mereka mempelajari sifat-sifat mulia seperti kesetiaan, rahmat, dan kasih sayang. Dari kehidupan keluarga, seorang bapak memperoleh dan memupuk sifat keberanian dan keuletan sikap dan upaya dalam rangka membela sanak keluarganya dan membahagiakan mereka pada saat dan setelah kematiannya.

${ }^{35}$ Quraish Shihab, op.cit., hlm. 255.

${ }^{36}$ Ibid., hlm. 255-256. 
Suatu keluarga tidak akan hidup tenang dan bahagia tanpa adanya suatu peraturan, kendali dan disiplin yang tinggi, begitu juga suatu negara. Kepincangan dalam menerapkan peraturan akan mengakibatkan kepincangan dalam kehidupan. ${ }^{37}$ Keluarga sebagai unit terkecil yang menjadi pendukung dan pembangkit lahirnya bangsa dan masyarakat. Selama pembangkit itu mampu menyalurkan arus yang kuat lagi sehat. Selama itu pula masyarakat bangsa akan menjadi sehat dan kuat pula.

Memimpin rumah tangga adalah satu tanggung jawab, demikian juga memimpin negara. Kepemimpinan suatu negara tidak mungkin tercapai apabila pemimpin-pemimpin daerah tidak berjalan searah dengan pimpin pusat. Kepemimpinan di setiap daerah tidak akan berhasil apabila langkah-langkah keluarga bertentangan dengan kepemimpinan daerah. Demikian terlihat keterkaitan yang erat antara langkah suatu keluarga dengan langkah suatu negara. Karena keluarga tidak lain merupakan tulang punggung suatu bangsa.

\section{Arah Filosofi Perkawinan di Islam}

Berdasarkan uraian di atas tentang filosofi perkawinan dalam Islam, maka terlihat bahwa Islam ingin membangun manusia yang baik. Hal itu tercermin dari adanya ritual akad nikah yang harus dilakukan sebagai pengikat antara laki-laki dengan perempuan untuk membuat sebuah ikatan janji membangun rumah tangga yang harmonis dan berbahagia. Sehingga dalam konteks ini tidak hanya dalam segi akibat hukum yang menghalalkan sesuatu yang haram. Namun lebih jauh dari itu, sebuah semangat untuk mewujudkan

${ }^{37}$ Ibid. 
sebuah masyarakat yang memiliki akhlak mulia dengan sesama manusia.

Dalam rangka untuk lebih mendalami dan mengetahui tentang filosofi perkawinan yang ada di dalam Islam, tidak ada salahnya untuk melihat pandangan Ali Ahmad al-Jurjawi tentang hikah-hikmah perkawinan. ${ }^{38}$ Antara lain:

1. Keadaan hidup manusia tidak akan tenteram kecuali apabila keadaan rumah tangganya teratur. Kehidupannya tidak akan tenang kecuali dengan adanya ketertiban rumah tangga.

2. Pernikahan dapat menghasilkan keturunan banyak sehingga dalam proses memakmurkan di bumi semakin mudah dalam menjalani hidup karena akan terasa sulit manakala dilakukan sendirian. Di mana perkawinan akan memelihara keturunan serta menjaganya.

3. Laki-laki dan perempuan adalah dua sekutu yang berfungsi memakmurkan dunia masing-masing dengan ciri khasnya berbuat dengan berbagai macam pekerjaan dengan saling melengkapi.

4. Sesuai dengan tabiatnya manusia itu cenderung ingin mengasihi seseorang. Sehingga dengan adanya istri, suami dapat mengasihi istrinya, begitu juga dengan adanya suami, istri dapat mengasihi suaminya.

5. Perkawinan akan menjaga pandangan yang penuh syahwat terhadap apa yang tidak dihalalkan untuknya.

${ }^{38}$ Selengkapnya bisa lihat Ali Ahmad al-Jurjawi, op.cit., hlm. 4-7. Lihat juga Hadi Mulyo dan Sobahus Surur, Falsafah dan Hikmah Hukum Islam, Semarang: AsySyifa, 1992, hlm. 256-258. Lihat juga Abd Rahman Ghazaly, op.cit., hlm. 65-69. 
Melengkapi hikmah dari perkawinan dalam kehidupan dunia dalam rangka membentuk masyarakat yang sejahtera, Sayyid Sabiq berpandangan bahwa perkawinan dapat membawa hikmah, ${ }^{39}$ sebagai berikut:

1. Sesungguhnya naluri seks merupakan naluri yang paling kuat yang selamanya menuntut adanya jalan keluar. Bilamana jalan keluar tidak dapat memuaskannya, maka banyaklah manusia yang mengalami kegoncangan, kacau dan menerobos jalan yang jahat. Kawin merupakan jalan alami dan biologis yang paling baik dan sesuai untuk menyalurkan dan memuaskan naluri seks ini.

2. Kawin merupakan jalan terbaik untuk menciptakan anak-anak menjadi baik, memperbanyak keturunan, melestarikan hidup manusia serta memelihara nasab yang oleh Islam sangat diperhatikan.

3. Naluri kebapakan dan keibuan akan tumbuh saling melengkapi dalam suasana hidup dengan anak-anak akan tumbuh pula perasaan-perasaan ramah, cinta dan sayang yang meruapakan sifat-sifat baik yang menyempurnakan kemanusiaan seseorang.

4. Menyadari tanggung jawab beristri dan menanggung anak-anak akan menimbulkan sikap rajin dan sungguh-sungguh dalam memperkuat bakat dan pembawaan seseorang.

5. Adanya pembagian tugas di mana yang satu mengurusi dan mengatur rumah tangga sedangkan yang lain bekerja di luar

${ }^{39}$ Sayyid Sabiq, op.cit., hlm 10-12, lihat juga M. Thalib, 40 Petunjuk Menuju Perkawinan Islami, Bandung: Irsyad Baitus Salam, hlm. 34-36. 
sesuai dengan batas-batas tanggung jawab antara suami istri dalam menangani tugas-tugasnya

6. Memperkuat hubungan kemasyarakat yang Islam yang direstui, ditopang dan ditunjang karena dengan ini masyarakat bisa saling menyayangi dan membantu.

Melihat uraian yang sudah dipaparkan di atas, maka hikmah dari perkawinan menyalurkan segala kebutuhannya di dalam institusi yang disebut dengan keluarga. Keluarga yang sejahtera akan berdampak pada kehidupan masyarakat sejahtera pula. Sehingga sangat terlihat bahwa filosofi adanya perkawinan dalam Islam untuk menciptakan kehidupan yang sejahtera dengan tatanan kehidupan yang baik dengan menata rapi keluarga sebagai fondasi dalam sebuah bangsa dan negara.

\section{E. Penutup}

Perkawinan merpuakan akad yang memberikan faedah hukum kebolehan mengadakan hubungan keluarga antara laki-laki dan perempuan dan mengadakan tolong-menolong dan memberi batas hak bagi pemiliknya serta pemenuhan kewajiban bagi masing-masing. Proses ini akan dianggap sah manakala terpenuhi syarat dan rukunnya, yakni dua mempelai, wali, saksi dan shighat ijab qabul. Pada awalnya hukum nikah adalah sebuah kebolehan, namun karena berbagai faktor hukum tersebut bisa menjadi wajib, sunah, mubah, makruh dan bahkan haram.

Dalam pandangan Islam, perkawinan ini dijadikan sebagai pedoman dan peraturan untuk kemaslahatan manusia. Terlebih bagi mereka sudah mampu baik dari segi fisik, mental dan juga 
keuangannya. Melalui perkawinan ini manusia boleh melakukan sesuatu yang sebelumnya diharamkan oleh syari'at Islam. Selain itu juga manusia dapat mendapatkan keturunan dan mereka bisa saling memenuhi kebutuhan.

Agama Islam mengatur manusia dalam hidup berjodoh-jodoh itu melalui jenjang perkawinan yang ketentuannya dirumuskan dalam wujud aturan-aturan yang disebut dengan hukum perkawinan. Hukum ini ada bukan tanpa adanya sebuah tujuan, namun hukum Islam juga ditetapkan ini untuk kesejahteraan umat, baik secara perorangan maupun secara bermasyarakat, baik untuk hidup di dunia maupun di akhirat. Kesejahteraan masyarakat dakan tercapai dengan terciptanya kesejahteraan keluarga yang sejahtera. Karena keluarga merupakan lembaga terkecil dalam masyarakat, sehingga kesejahteraan masyarakat sangat tergantung kepada kesejahteraan keluarga.

Adapun hikmah dari perkawinan sebanyak sekali, di antaranya perkawinan merupakan jalan terbaik untuk menciptakan anak-anak menjadi baik, memperbanyak keturunan, melestarikan hidup manusia serta memelihara nasab yang oleh Islam sangat diperhatikan. Selain itu juga perkawinan juga Kawin merupakan jalan alami dan biologis yang paling baik dan sesuai untuk menyalurkan dan memuaskan naluri seks ini dan lain sebagainya

\section{Daftar Pustaka}

al-Anshary, Abu Yahya Zakariya, Fath al-Wahhab, Singapura: Sulaiman Mar'iy, t.t.

al-Asqalani, Ibnu Hajar, Bulugh al-Maram, Beirut: Dar al-Ihya' alUlum, 1991.

al-Ghazaly, Abd Rahman, Fiqh Munakahat, Jakarta: Kencana, 1996. 
al-Jurjawi, Ali Ahmad, Hikmah al-Tasyri' wa Falsafatuhu, Juz. II, Beirut: Dar al-Fikr, 1994.

al-Kahlaniy, Muhammad Ismail bin Ismail, Subul al-Salam, bandung: Dahlan, t.t.

al-Zuhaili, Wahbah, al-Fiqh al-Islami wa Adillatuh, Beirut: Dar alFikr, 1989.

Daradjat, Zakiah, Ilmu Fiqh, Yogyakarta: Dana Bhakti Wakaf, 1995.

Dep Dikbud, Kamus Besar Bahasa Indonesia, Jakarta: Balai Pustaka, 1994.

Departemen Agama RI, al-Qur'an dan Terjemahannya, Bandung: Syaamil Cipta Media, 2005.

Gazalba, Sidi, Siatematika Filsafat, jlid. I, Jakarta: Bulan Bintang, 1967.

Huijbers, Theo, Filsafat Hukum, Yogyakarta: Kanusius, 1995.

Munawwir, Ahmad Warson, Al-Munawwir Kamus Arab - Indonesia,

Cet. XXV, Surabaya: Pustaka Progessif, 2002

Sabiq, Sayyid, Fiqh al-Sunnah, jilid. 3, Beirut: Dar al-Fikr, 1983.

Shihab, Quraish, Membumikan al-Qur'an, Cet. VII, Bandung: Mizan, 1994.

Undang-undang Nomor 1 Tahun 1974 tentang Perkawinan 